\title{
Direct Arterial Pressure and Electrocardiogram during Motor Car Driving
}

\author{
W. A. LITTLER, A. J. HONOUR, P. SLEIGHT
}

British Medical fournal, 1973, 2, 273-277

\section{Summary}

Direct arterial pressure and electrocardiogram have been measured continuously over a period of 24 hours in 15 patients, Observations have been made on the behaviour of these variables during $\mathbf{3 0}$ separate episodes of motor car driving. The patients were divided into three groups: (1) five normotensive subjects, (2) five patients with essential hypertension who were not receiving therapy, and (3) five patients with angina pectoris who were either normotensive or hypertensive.

In all but one subject, apart from variable changes in heart rate, no significant arrhythmias or S-T segment changes were observed in the electrocardiogram. The arterial pressure remained remarkably stable throughout the driving period in all three groups and there was no significant difference between the levels of blood pressure at the beginning and end of a journey. There were short periods of raised arterial pressure during driving related to such episodes as overtaking, but these quickly returned to baseline levels. Two patients experienced anginal pain during driving.

It is concluded that motor car driving does not have such a pronounced effect on the blood pressure as might have been thought.

\section{Introduction}

Driving a motor car often induces emotional stress in normal people and can provoke angina pectoris in patients with ischaemic heart disease. A number of studies of the electro-

\section{Radclifie Infirmary, Oxford OX2 6HE}

W. A. ITTTIER, M.D, M.R.C.P., Lecturer in Medicine, Cardiac Department W. A. LITTLER, M.D., M.R.C.P., Lecturer in Medicine, Cardiac Departmen A. J. HONOUR, M.A., D.P

P. SLEIGHT, M.D., F.R.C.P., Consultant Physician, Cardiac Department

cardiogram recorded during motor car driving have shown quite definite S-T segment changes and arrhythmias even in normal people as well as large changes in heart rate (Bellet et al.. 1968; Taggart et al., 1969; Meeran, 1972).

In this report we document the behaviour of the direct arterial pressure and the electrocardiogram during periods of motor car driving in unrestricted subjects.

\section{Patients and Methods}

Altogether, 15 patients were studied, selected from a group in whom the direct arterial pressure and electrocardiogram had been measured over a 24-hour period. The 15 patients were chosen because they had driven their cars at some stage during the 24 -hour period. Throughout this period they were completely unrestricted and went about their normal routine. The study was not specifically designed to observe the effects of motor car driving (while doing so the patient was not under the extra stress of being scrutinized specifically for this purpose by a doctor).

They were divided into three groups: (1) five normal patients (who were normotensive at rest and had a normal electrocardiogram and chest radiograph), (2) five patients with essential hypertension who had not received hypotensive therapy, and (3) five patients with classical angina pectoris. Full details are given in table $I$.

The methods used for measuring direct arterial pressure and the electrocardiogram in unrestricted patients have been fully described in previous publications (Littler et al., 1972). Briefly, a Tefion catheter (length $10 \mathrm{~cm}$, internal diameter $0.9 \mathrm{~mm}$ ) was inserted into the left brachial artery using the Seldinger technique. The catheter was connected to a transducer and perfusion pump by a 1-m length of Teflon tubing $0.35 \mathrm{~mm}$ internal diameter, and was perfused with normal saline at about $1.5 \mathrm{ml} / \mathrm{hr}$. The recording system was a miniature (four-channel analogue) tape recorder using standard

TABLE I-Details of Patients Taking Part in Study

\begin{tabular}{|c|c|c|c|c|c|c|c|}
\hline Case No. & Age & Sex & Occupation & Resting E.C.G. & Chest Radiograph & Medication & Resting B.P. (mm Hg) \\
\hline \multicolumn{8}{|c|}{ Normotensive } \\
\hline $\begin{array}{l}1 \\
2 \\
3 \\
4 \\
5\end{array}$ & $\begin{array}{l}37 \\
39 \\
68 \\
32 \\
45\end{array}$ & $\begin{array}{l}\text { M. } \\
\text { M. } \\
\text { F. } \\
\text { M. }\end{array}$ & $\begin{array}{l}\text { Heating Engineer } \\
\text { Scientist } \\
\text { Actuary } \\
\text { Psychologist } \\
\text { Clerk }\end{array}$ & $\begin{array}{l}\text { Normal } \\
\text { Normal } \\
\text { Normal } \\
\text { Normal } \\
\text { Normal }\end{array}$ & $\begin{array}{l}\text { Normal } \\
\text { Normal } \\
\text { Normal } \\
\text { Normal } \\
\text { Normal }\end{array}$ & $\begin{array}{l}\bar{z} \\
\bar{z}\end{array}$ & $\begin{array}{l}150 / 85 \\
125 / 80 \\
150 / 95 \\
100 / 60 \\
120 / 65\end{array}$ \\
\hline \multicolumn{8}{|c|}{ Hypertensives } \\
\hline $\begin{array}{r}6 \\
7 \\
8 \\
9 \\
10\end{array}$ & $\begin{array}{l}19 \\
37 \\
55 \\
55 \\
42\end{array}$ & $\begin{array}{l}\text { M. } \\
M . \\
M . \\
M . \\
M .\end{array}$ & $\begin{array}{l}\text { Apprentice } \\
\text { Scientist } \\
\text { Schoolmaster } \\
\text { Accountant } \\
\text { Motor mechanic }\end{array}$ & $\begin{array}{l}\text { LV+ } \\
\text { L.A.H. } \\
\text { Normal } \\
\text { Normal } \\
\text { Normal }\end{array}$ & $\begin{array}{l}\text { Normal } \\
\text { LV+ } \\
\text { Normal } \\
\text { LV+ } \\
\text { Normal }\end{array}$ & $\begin{array}{l}= \\
=\end{array}$ & $\begin{array}{l}190 / 100 \\
210 / 125 \\
180 / 120 \\
190 / 115 \\
200 / 120\end{array}$ \\
\hline \multicolumn{8}{|c|}{ Ischaemic Heart Disease } \\
\hline 11 & $\begin{array}{l}52 \\
57\end{array}$ & $\begin{array}{l}\text { M. } \\
\text { M. }\end{array}$ & $\begin{array}{l}\text { Builder } \\
\text { Factory worker }\end{array}$ & $\begin{array}{l}\text { L.A.H. } \\
\text { Normal rest } \\
\text { Positive exercise test }\end{array}$ & $\begin{array}{l}\text { Normal } \\
\text { Normal }\end{array}$ & \multirow{2}{*}{$\begin{array}{l}\text { GTN } \\
\text { GTN Practolol } \\
100 \mathrm{mg} \text { t.d.s. } \\
\text { GTN } \\
\text { Diazepam } \\
\text { GTN } \\
\text { Practolol } 100 \mathrm{mg} \text { t.d.s. }\end{array}$} & $\begin{array}{l}170 / 110 \\
180 / 110\end{array}$ \\
\hline $\begin{array}{l}13 \\
14 \\
15\end{array}$ & $\begin{array}{l}58 \\
60 \\
53\end{array}$ & $\begin{array}{l}\text { M. } \\
\text { M. } \\
\text { M. }\end{array}$ & $\begin{array}{l}\text { Building worker } \\
\text { Technical instructor } \\
\text { Skilled labourer }\end{array}$ & $\begin{array}{l}\text { L.A.H. } \\
\text { R.B.B.B. ischaemia } \\
\text { S-T depression, aVL }\end{array}$ & $\begin{array}{l}\text { Normal } \\
\text { LV+ } \\
\text { Normal }\end{array}$ & & $\begin{array}{l}130 / 90 \\
125 / 95 \\
120 / 80\end{array}$ \\
\hline
\end{tabular}


compact cassettes. The transducer, perfusion pump, and tape recorder were carried in a padded harness at heart level; the reference point for pressure was therefore constant irrespective of the position of the arm. The frequency response of the whole system was flat to $10 \mathrm{~Hz}$. The electrocardiogram system consisted of bipolar electrodes placed over the V5R-V5L positions. Leads were held in place by electrode discs and secured by surgical tape to minimize movement artefact. The tape cassettes were replayed on a separate playback deck at 25 times the recording speed. The output from this playback deck was fed into an ultraviolet recorder so that compressed or expanded records, for beat-to-beat analysis, might be obtained. The patients were all studied over a 24-hour period from 9 a.m. to 9 a.m. During this time they attended the laboratory only once for 15 minutes after a 12-hour period in order to apply a calibration to the tape and to service the perfusion chamber.

Significant events were recorded both on the tape and in a diary kept by the patient. Only those driving episodes which are clearly indicated by the patient (precise beginning and end) are included in this study. Most episodes of driving included a period in the city of Oxford.

When analysing the data the heart rate and arterial pressure were averaged over periods of two minutes throughout the duration of driving. The figures given in table II are the average of all these two-minute averages obtained during the period of driving. Arrhythmias were judged significant if there was a change in rhythm or if ectopic beats occurred at more than three per minute or in runs of three or more. The S-T segment was said to be significantly depressed if the depression was flat, $1 \mathrm{~mm}$ or more in depth, lasting for 0.08 $\mathrm{sec}$ or more, and was seen in at least three consecutive beats.

\section{Results}

\section{HEART RATE (TABLE II)}

Normals. - The average heart rates in all but one journey (case 4) were less than $100 / \mathrm{min}$ and similarly the range of rates was fairly restricted (72-135). In general there was no significant difference in rate at the end of the journey as compared with the beginning (average-start 93, finish 94).

Hypertensives.-The average and peak rates tended to be a little higher in this group as compared to the normals, though the highest rate achieved was only 120/min (range 70-120). Once again, the rates at the beginning and end of the journey were not significantly different (average-start 90, finish 91).

Ischaemic Heart Disease.-The range of heart rates was compact with only one patient (case 14) reaching peaks of over $100 / \mathrm{min}$ (range 75-135). The rates at the end of the journey were not significantly increased as compared to the start (average-start 94, finish 96).

TABLE II-Results of Studies in Three Groups of Patients

\begin{tabular}{|c|c|c|c|c|c|c|c|c|c|c|c|}
\hline $\begin{array}{l}\text { Case } \\
\text { No. }\end{array}$ & $\begin{array}{c}\text { No. of } \\
\text { Journeys }\end{array}$ & $\begin{array}{c}\text { Time } \\
\text { of Day }\end{array}$ & $\underset{(\min )}{\text { Duration }}$ & $\begin{array}{c}\text { B.P. Start } \\
\text { Driving } \\
\text { (mm Hg) }\end{array}$ & $\begin{array}{c}\text { B.P. Finish } \\
\text { Driving } \\
\text { (mm Hg) }\end{array}$ & $\begin{array}{c}\text { Average } \\
\text { B.P. Driving } \\
\text { (mm Hg) }\end{array}$ & $\begin{array}{c}\text { Heart Rate } \\
\text { Start } \\
\text { (peats/min) }\end{array}$ & $\begin{array}{c}\text { Heart Rate } \\
\text { Finish } \\
\text { (beats/min) }\end{array}$ & $\left|\begin{array}{c}\text { Heart Rate } \\
\text { Average (Range) } \\
\text { (beats } / \text { min) }\end{array}\right|$ & $\underset{\text { Segments }}{\text { S-T }}$ & Arrhythmias \\
\hline \multicolumn{12}{|c|}{ Normotensive } \\
\hline \multirow[t]{2}{*}{1} & \multirow[t]{2}{*}{1} & A.M. & 40 & $110 / 60$ & $110 / 65$ & $110 / 62$ & 90 & 99 & \multirow{8}{*}{$\begin{array}{c}92 \\
(90-99) \\
90 \\
(90-96) \\
82 \\
(72-96) \\
93 \\
72 \\
(69-78) \\
120 \\
(96-135) \\
96 \\
(96-126) \\
90 \\
96 \\
(84-105) \\
90 \\
(90)\end{array}$} & Normal & None \\
\hline & & A.M. & 30 & $170 / 90$ & $155 / 98$ & $140 / 90$ & 93 & 90 & & $"$ & " \\
\hline 2 & 3 & P.M. & 40 & $150 / 75$ & $125 / 90$ & $132 / 97$ & 72 & 84 & & " & ” \\
\hline 3 & 1 & $\begin{array}{l}\text { A.M. } \\
\text { P.M. }\end{array}$ & $\begin{array}{l}30 \\
45\end{array}$ & $\begin{array}{l}140 / 80 \\
145 / 84\end{array}$ & $\begin{array}{l}140 / 65 \\
135 / 77\end{array}$ & $\begin{array}{l}125 / 60 \\
140 / 82\end{array}$ & $\begin{array}{l}91 \\
78\end{array}$ & $\begin{array}{l}93 \\
69\end{array}$ & & "' & ", \\
\hline & & A.M. & 20 & $120 / 56$ & $110 / 52$ & $104 / 50$ & 117 & 120 & & $"$ & $"$ \\
\hline 4 & 3 & P.M. & 20 & $132 / 82$ & $120 / 64$ & $128 / 72$ & 105 & 120 & & ” & " \\
\hline \multirow{2}{*}{5} & \multirow{2}{*}{2} & $\begin{array}{l}\text { P.M. } \\
\text { P.M. }\end{array}$ & $\begin{array}{l}25 \\
30\end{array}$ & $\begin{array}{l}140 / 80 \\
155 / 70\end{array}$ & $\begin{array}{l}114 / 56 \\
113 / 65\end{array}$ & $\begin{array}{l}124 / 68 \\
120 / 57\end{array}$ & $\begin{array}{l}90 \\
99\end{array}$ & $\begin{array}{l}94 \\
84\end{array}$ & & ", & ", \\
\hline & & A.M. & 10 & $150 / 65$ & $118 / 62$ & $120 / 55$ & 90 & 90 & & ” & " \\
\hline \multicolumn{12}{|c|}{ Hypertensive } \\
\hline \multirow{2}{*}{6} & \multirow{2}{*}{2} & A.M. & 40 & $210 / 130$ & $200 / 135$ & $200 / 130$ & 93 & 96 & $\begin{array}{c}97 \\
(84-114)\end{array}$ & $"$ & $"$ \\
\hline & & P.M. & 40 & $210 / 115$ & $190 / 100$ & $190 / 100$ & 90 & 84 & $\begin{array}{c}80 \\
(75-84)\end{array}$ & " & " \\
\hline \multirow{3}{*}{7} & \multirow{3}{*}{2} & P.M. & 40 & $224 / 134$ & $220 / 130$ & $200 / 130$ & 96 & 111 & $\begin{array}{c}104 \\
(90-120)\end{array}$ & ” & " \\
\hline & & P.M. & 25 & $204 / 132$ & $210 / 132$ & $180 / 132$ & 81 & 96 & $\begin{array}{c}84 \\
(72-96)\end{array}$ & ” & " \\
\hline & & A.M. & 60 & $230 / 100$ & $185 / 98$ & $190 / 94$ & 87 & 70 & $\begin{array}{c}78 \\
(70-90)\end{array}$ & " & " \\
\hline 8 & 4 & $\begin{array}{l}\text { A.M.I } \\
\text { P.M. }\end{array}$ & $\begin{array}{r}5 \\
50\end{array}$ & $\begin{array}{l}220 / 102 \\
220 / 93\end{array}$ & $\begin{array}{l}195 / 95 \\
210 / 93\end{array}$ & $\begin{array}{l}195 / 95 \\
195 / 93\end{array}$ & $\begin{array}{l}80 \\
75\end{array}$ & $\begin{array}{l}80 \\
72\end{array}$ & $\begin{array}{c}80 \\
72 \\
(72-75)\end{array}$ & "' & P.ß̈.s \\
\hline 9 & 1 & $\begin{array}{l}\text { P.M. } \\
\text { P.M. }\end{array}$ & $\begin{array}{l}50 \\
30\end{array}$ & $\begin{array}{l}220 / 94 \\
190 / 110\end{array}$ & $\begin{array}{l}165 / 88 \\
195 / 107\end{array}$ & $\begin{array}{l}180 / 90 \\
195 / 110\end{array}$ & $\begin{array}{r}84 \\
117\end{array}$ & $\begin{array}{r}84 \\
120\end{array}$ & $\begin{array}{c}(72-70) \\
84 \\
118 \\
(114-120)\end{array}$ & " & $\begin{array}{l}\text { P.B.s } \\
\text { None }\end{array}$ \\
\hline 10 & 1 & A.M. & 30 & $236 / 140$ & $212 / 130$ & $220 / 130$ & 105 & 102 & $\begin{array}{c}107 \\
(102-120)\end{array}$ & " & " \\
\hline \multicolumn{12}{|c|}{ Ischaemic Heart Disease } \\
\hline \multirow{2}{*}{11} & \multirow{2}{*}{3} & $\begin{array}{l}\text { A.M. } \\
\text { A.M. }\end{array}$ & $\begin{array}{l}45 \\
15\end{array}$ & $\begin{array}{l}138 / 65 \\
125 / 62\end{array}$ & $\begin{array}{l}135 / 65 \\
125 / 68\end{array}$ & $\begin{array}{l}135 / 65 \\
120 / 62\end{array}$ & $\begin{array}{l}90 \\
84\end{array}$ & $\begin{array}{l}90 \\
82\end{array}$ & $\begin{array}{c}90 \\
82 \\
(75-87)\end{array}$ & ", & " \\
\hline & & P.M. & 20 & $200 / 115$ & $180 / 110$ & $182 / 110$ & 90 & 96 & $(90-96)$ & " & $"$ \\
\hline 12 & 1 & P.M. & 15 & $144 / 95$ & $156 / 95$ & $144 / 95$ & 84 & 93 & $\begin{array}{r}89 \\
(84-93)\end{array}$ & " & " \\
\hline 13 & 1 & P.M. & 20 & $190 / 106$ & $166 / 88$ & $170 / 97$ & 90 & 96 & $\begin{array}{l}92 \\
(90-99)\end{array}$ & " & " \\
\hline \multirow{3}{*}{14} & \multirow{3}{*}{2} & A.M. & 50 & $172 / 100$ & $159 / 100$ & $130 / 98$ & 108 & 135 & $\begin{array}{c}125 \\
(108-135)\end{array}$ & ” & ” \\
\hline & & P.M. & 45 & $185 / 100$ & $175 / 112$ & $165 / 110$ & 120 & 102 & $\begin{array}{c}109 \\
(102-120)\end{array}$ & " & " \\
\hline & & P.M. & 25 & $200 / 80$ & $180 / 75$ & $180 / 75$ & 99 & 94 & $\begin{array}{l}92 \\
(90-99)\end{array}$ & " & $"$ \\
\hline \multirow[t]{2}{*}{15} & \multirow[t]{2}{*}{3} & P.M. & 25 & $200 / 75$ & $168 / 70$ & $190 / 70$ & 93 & 87 & $\begin{array}{l}93 \\
(87 \mathrm{~g} 99)\end{array}$ & $"$ & " \\
\hline & & A.M. & 20 & $150 / 75$ & $150 / 75$ & $150 / 75$ & 90 & 90 & 90 & $"$ & " \\
\hline
\end{tabular}

P.B.s $=$ Premature beats. 


\section{ARRHYTHMIAS}

Only one patient (case 8) developed a significant arrhythmia during driving, this consisted of multiple ventricular ectopic beats (fig. 1).

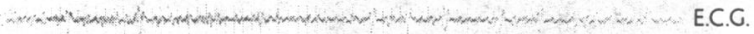

250

200

150 .

100

(

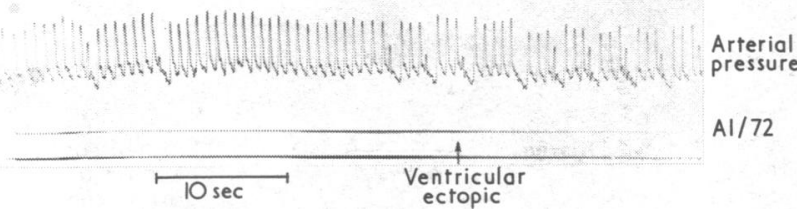

FIG. 1-Part of a record obtained from case 8 while driving, showing multiple ventricular ectopic beats.

\section{S-T SEGMENT CHANGE}

We did not observe any significant $S-T$ segment changes in any of the 15 patients.

\section{ARTERIAL PRESSURE}

The remarkable thing about these observations was the relative stability of the arterial pressure during driving.

Normals.-Table II shows that these journeys did not significantly raise the arterial pressure. Examples from case 1 (figs. 2 and 3 ) and case 3 (fig. 4) illustrate how stable the arterial pressure remained throughout the journey. The surge of pressure at the end of the journey shown in fig. 4 was real but did not relate to any particular incident.

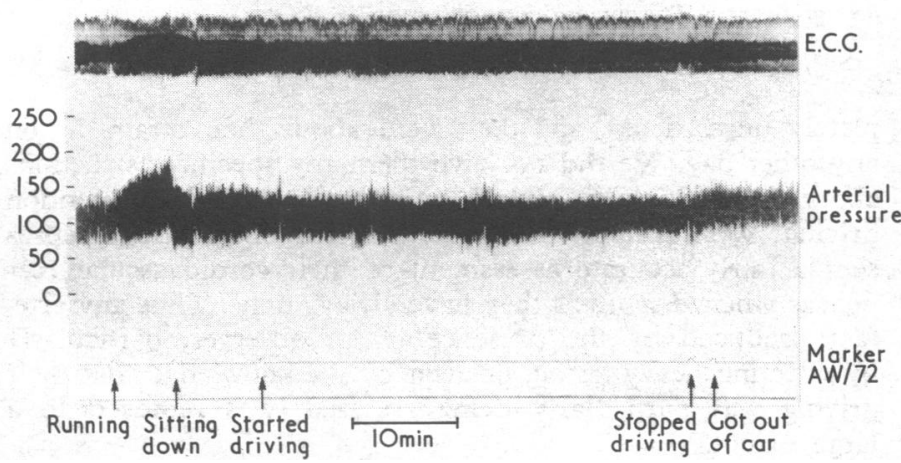

FIG. 2-Record obtained from a normal subject (case 1) while driving. Note the relative stability of arterial pressure during driving; short rises in pressure were probably related to overtaking.

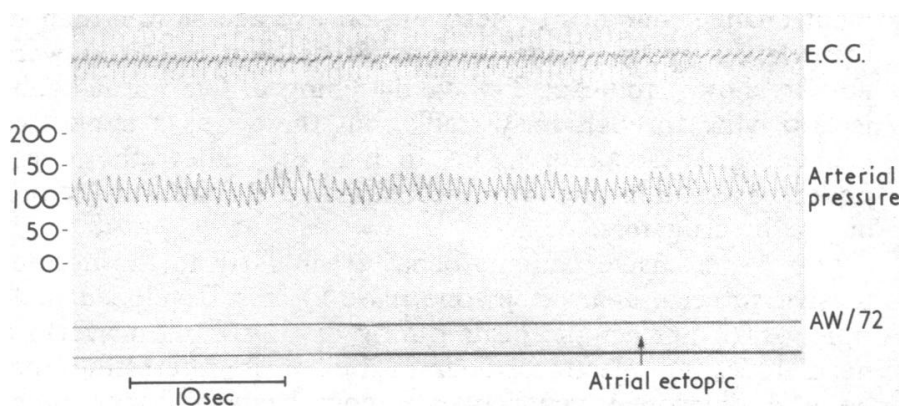

FIG. 3-A beat-to-beat analysis of part of driving episode illustrated in fig. 2, emphasizing the steadiness of arterial pressure; an occasional atrial ectopic beat is shown.

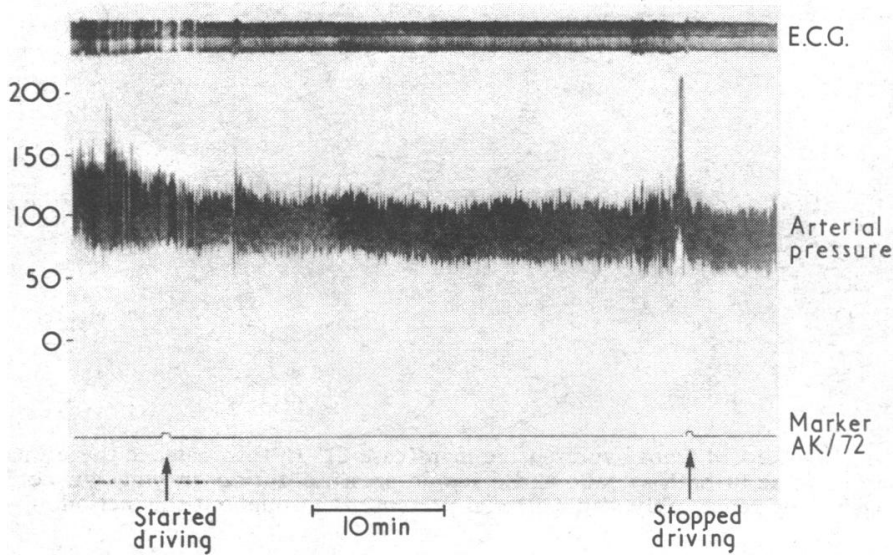

FIG. 4-Record from normotensive subject (case 3). Sudden short surge of pressure when car was stopped did not relate to any particular stress.

Hypertensives.-Table II again indicates how little effect the journey has had on the arterial pressure. The steady nature of the pressure during driving with a short surge of pressure towards the end where a patient was parking his vehicle is shown in fig. 5. Compare this with the sharp rise in his pressure when he was driven by his wife (fig. 6). However, the
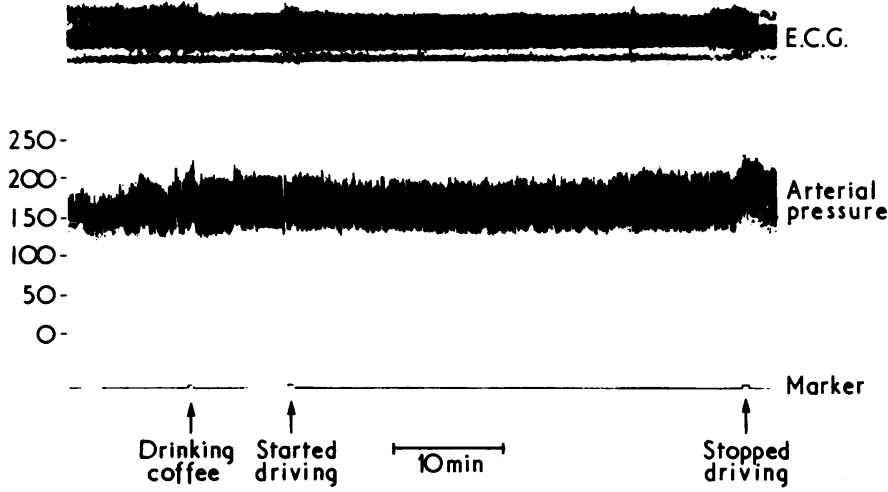

FIG. 5-Record from hypertensive man (case 7) illustrating remarkably even arterial pressure during period of driving.
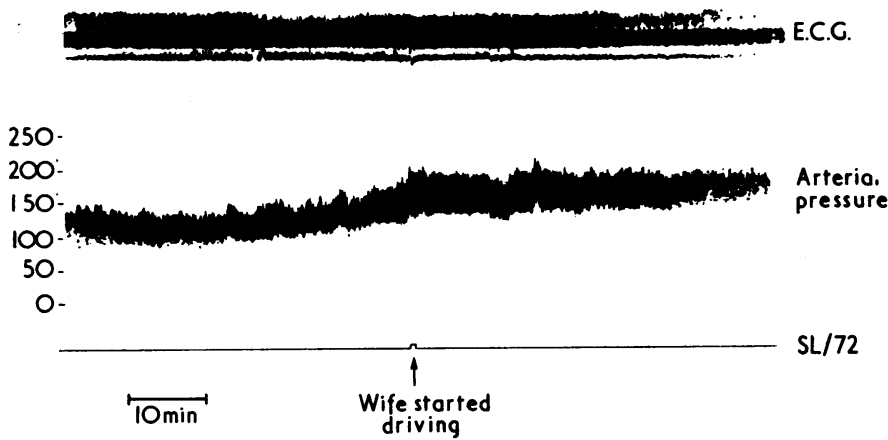

FIG. 6-Record from case 7 illustrating an increase in arterial pressure when patient was driven by his wife.

level of arterial pressure reached during his wife's driving was in fact no higher than that when the patient drove himself. An episode of driving where there has been a rise in both the systolic and diastolic pressures during driving is shown in fig. 7, but again the overall behaviour is extremely steady. This patient was the only one to show a significant arrhythmia during driving (fig. 1). 


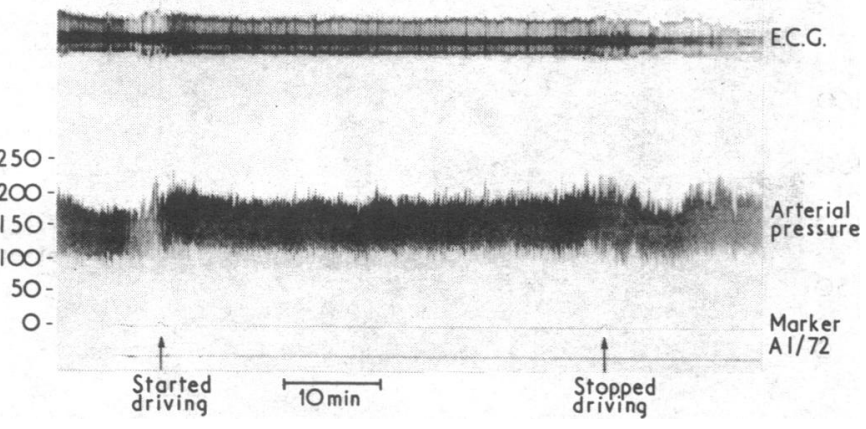

FIG. 7-Record from hypertensive man (case 8). In this instance there was an increase in both systolic and diastolic pressure during driving, but note again how remarkably stable arterial pressure is throughout this period.

Ischaemic Heart Disease.-The behaviour overall of the arterial pressure is similar to that in the other two groups. The steady nature of the arterial pressure during a driving episode is shown in fig. 8. This record shows several short rises in systolic and diastolic pressure superimposed on a steady record. The patient indicated in his diary that these were probably related to overtaking.

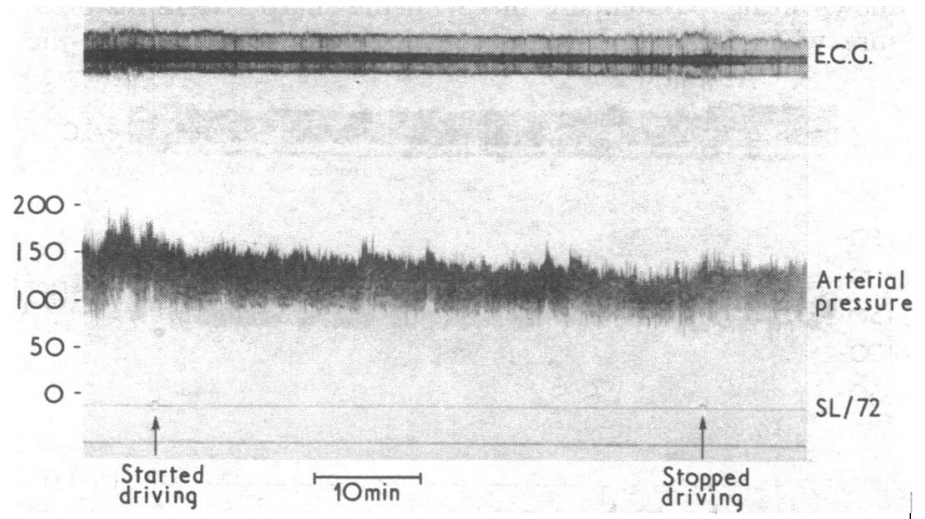

FIG. 8-Record from a patient with angina pectoris (case 13). Short lasting peaks of arterial pressure are related to episodes of overtaking and traffic congestion.

\section{ANGINA PECTORIS}

Two patients (cases 11 and 13) developed angina pectoris during driving. One (case 13) described it as only "mild discomfort" and there were no obvious haemodynamic changes. The S-T segments did not alter during the whole journey. The other patient (case 11) was forced to stop his car because of pain (fig. 9); there was a short rise in arterial pressure (and heart rate) with the subjective appreciation of pain but the arterial pressure before this was remarkably stable. No significant S-T segment change was observed in the electrocardiogram (fig. 10).

\section{Discussion}

Motor car driving, especially under difficult conditions, is considered to be one of the more exacting experiences of modern life, and the frequency of coronary episodes during driving is assumed to be associated with adverse changes in the cardiovascular system. It is well known that episodes of acute coronary insufficiency may result in road traffic accidents (Hoffmann, 1963; Bellet et al., 1968).

The patients taking part in our study were involved in a 24-hour assessment of the behaviour of their arterial pressure, heart rate, and electrocardiographic pattern; they were com-

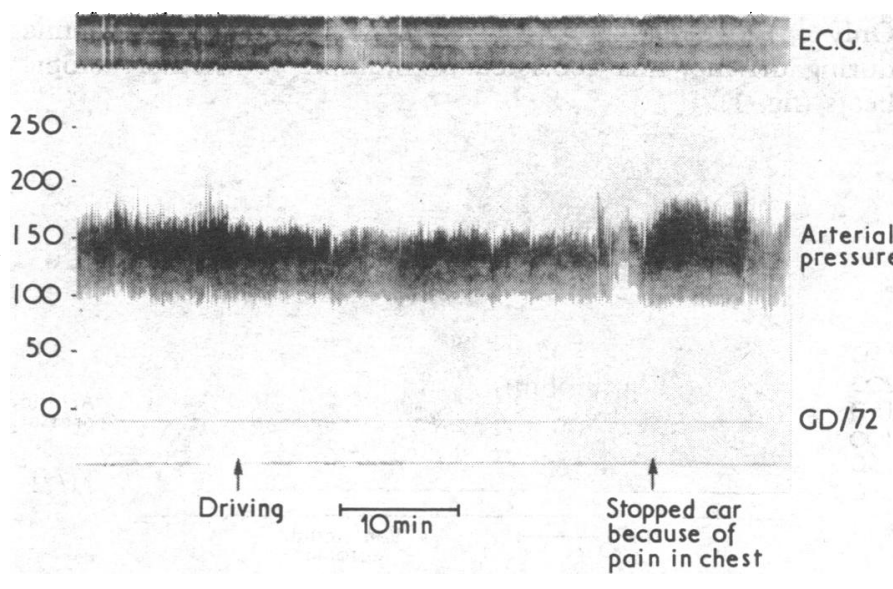

FIG. 9-Record from a patient with angina pectoris (case 11) who was forced to stop his car because of a chest pain. Notice steady arterial pressure during most of driving period, and sudden increase in arterial pressure coinciding with onset of chest pain.
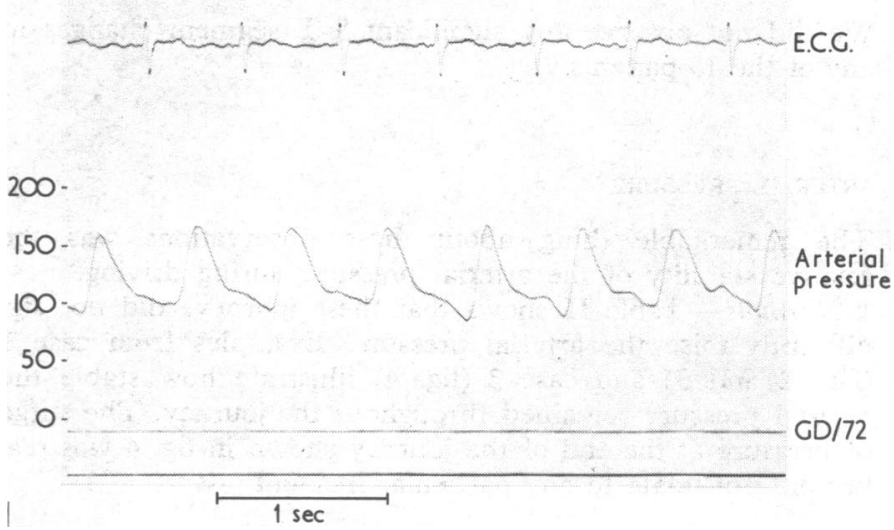

FIG. 10-Beat-to-beat analysis of part of fig. 9, during chest pain. There is no significant $S-T$ segment depression in the E.C.G.

pletely unrestricted, and they went about their affairs as on any other day. We did not give them any specific instructions about their activities, and in particular we did not mention driving. We consider, therefore, that our observations represent a fairly accurate assessment of their cardiovascular responses when driving as they have always done. Thus any artefact produced by the presence of an observer, particularly by selecting heavy traffic, or even by the knowledge that their driving was particularly being assessed, was removed to a large extent.

The numbers were, for obvious reasons, far fewer than in the studies where the electrocardiogram alone has been monitored. However, the heart rate and electrocardiographic behaviour was similar to that found by Bellet and his colleagues (1968), who also did not find any significant S-T segment change; our heart rates were on average slower than in their larger group. Taggart and his colleagues (1969) were able to show significant $T$-wave flattening in five normal subjects driving through busy traffic, but there was a subjective element in these observations in that they knew they were under observation and were accompanied throughout by one of the investigators.

Our hypertensive patients behaved similarly to the normotensive subjects apart from one (case 8) who developed multiple ventricular ectopic beats during driving. This man had a normal resting electrocardiogram but it is interesting that he also developed ventricular ectopic beats at other times during the 24-hour period, related to physical exertion. He may well therefore have underlying coronary artery disease. 
We did not observe any significant S-T segment changes in the two patients with angina pectoris who developed chest pain. One (case 13) had only "mild discomfort" and produced no significant haemodynamic changes, while the other (case 11) was forced to stop his car quickly because of pain (fig. 9). A sudden increase in arterial pressure, particularly the diastolic value, occurred with the subjective appreciation of pain, but the electrocardiogram remained normal. We have observed similar changes in attacks of angina pectoris in other circumstances (Littler et al., 1973).

The studies of Hoffman (1963), Bellet et al. (1968), and Taggart et al. (1969) all showed S-T segment and T-wave changes in a number of their patients with ischaemic heart disease during driving - in Taggart's series as many as $59 \%$ of the total-however, only two patients $(8 \%)$ developed frank angina pectoris. We accept that our lead system may not have detected the ischaemic change in these instances (Littler et al., 1972).

Heart rate changes were not obviously different in our three groups of patients who in this respect responded to driving in the same way.

Few observations have been made on the behaviour of the arterial pressure during motor car driving. From this laboratory Beven et al., (1969), using an earlier version of the present method for measuring direct arterial pressure, reported that there was no significant change in arterial pressure during short-term journeys in three patients, one of whom had malignant hypertension. We have not been able to find any other such observations. Our observations confirm that arterial pressure remains remarkably stable during driving. We are not able to comment on its behaviour during busy "rush hour" traffic such as occurs in London. However, most of our patients did drive from outside and through the city of Oxford where the traffic density creates real problems, the traffic on the roads leading into the city being at times dense and occasionally hazardous. There were occasional surges in arterial pressure (figs. 2 and 8 ) while related to such things as overtaking, but these were short-lived, and overall arterial pressure was little different at the end of a journey as compared with its beginning. Patients with hypertension behaved in a similar way to normotensives. An interesting example of the effect of being driven by another person can be seen in fig. 6. This was atypical: other patients who were driven tended to behave in a similar fashion to that while driving. It should be remembered, however, that the levels achieved during this episode (fig. 6) were no higher than when the patient was driving himself.

Of two patients who developed chest discomfort while driving, one (case 13) had no significant pressure change while the other (case 11) began to show pressure changes after pain started. This pattern has been noted in other cases of anginal pain (Littler et. al., 1973) and suggests that this rise of pressure reaction is an effect rather than the cause of the pain.

Recently Aronow and his colleagues (1972) have suggested that the occurrence of angina pectoris during motor car driving may be related to increased levels of arterial carboxyhaemoglobin produced by atmospheric carbon monoxide pollution from car exhaust fumes. These workers studied 10 patients with angina in the resting state, after being driven for 90 minutes during heavy morning "freeway traffic," and two hours after return. The study was repeated 24 hours later while breathing "compressed purified air." Exposure to heavy freeway traffic increased arterial carboxyhaemoglobin levels causing angina to develop sooner after less cardiac work, presumably on the basis of reducing myocardial oxygen tension. S-T segment depression occurred in three patients while breathing freeway air but not after breathing compressed purified air.

It is interesting to note that these workers found no significant difference in resting systolic and diastolic arterial pressures or resting heart rate immediately after the period of driving as compared to the control period or two hours later; findings which are in keeping with our own observations.

Thus it would appear that the arterial pressure of people driving motor cars is much more stable than might have been expected.

We are grateful to Dr. F. D. Stott for invaluable technical advice. This work is supported in part by a grant from the British Heart Foundation.

\section{References}

Aronow, W. S., Harris, C. N., Isbell, M. W., Rokaw, M. D., and Imparato, B. (1972). Annals of Internal Medicine, 77, 669

Bellet, S., Roman, L., Kostis, J., and Slater, A. (1968). American fournal of Cardiology, 22, 856 .

Cardiology, 22, 856. I. and Stott, F. D. (1969). Clinical Science, 36, 329. Bevan, A. T., Honour, A. J., and Stott, F. D. (1969). Clinical Science, 36, 32 Hoffimann, H. (1963). Münchener Medizinische Wochenschrift, 105, 190 . Littler, W. A., Honour, A.
Medical Yournal, 3, 76.

Littler, W. A., Honour, A. J., Sleight, P., and Stott, F. D. (1973). Circulation, In press.

Meeran, M. K. (1972). In New Perspectives in B-blockade, p. 23. Horsham, Sussex, CIBA Laboratories.

Taggart, P., Gibbons, D., and Somerville, W. (1969). British Medical fournal, 4, 130.

\section{Summary}

Two cases are presented of sarcomata arising at the site of previous iron dextran injections. One of the tumours showed a histological pattern associated with iron dextran administration in animal experiments.

\section{Introduction}

The development of fibrosarcoma in animals after iron dextran injections was first reported by Richmond (1957, 1959) and subsequently by other workers (Golberg et al., 1960; Fielding, 1962; Haddow et al., 1964; Roe et al., 1964; Roe and Haddow, 1965; Carter et al., 1968). Tumours of other histological types have also been reported (Roe et al., 1964; Langvad, 1966, 1968; Carter et al., 1968). In man neoplasia has twice been recorded in association with iron dextran therapy. One was a fibrosarcoma (Robinson et al., 1960), the other a secondary deposit from a squamous cell carcinoma (Crowley and Still, 1960). The present report concerns two patients, one developing a reticulum cell sarcoma, the other a pleomorphic sarcoma. 